Published in: Fütterer, D K, Damaske, D, Kleinschmidt, G, Miller, H \& Tessensohn, F (eds.), Antarctica: contributions to global earth sciences, Springer, Berlin, Heidelberg, New York, 63-68

http://dx.doi.org/10.1007/3-540-32934-X

The original publication is available at http://www.springerlink.com see

http://dx.doi.org/10.1007/3-540-32934-X 9

Data are available at: http://dx.doi.org/10.1594/PANGAEA.611692

\title{
Tectonic Subdivision of the Prince Charles Mountains: A Review of Geologic and Isotopic Data
}

\author{
Evgeny V. Mikhalsky' ${ }^{1}$ Anatoly A. Laiba ${ }^{2} \cdot$ Boris V. Beliatsky \\ (1) VNIIOkeangeologia, Angliysky Avenue1, St. Petersburg 190121, Russia \\ (2) PMGRE, Pobeda Street 24, Lomonosov 189510, Russia \\ (3) IGGP, Makarova emb. 2, 199034 St. Petersburg 199034, Russia
}

\begin{abstract}
The Prince Charles Mountains have been subject to extensive geological and geophysical investigations by former Soviet,Russian and Australian scientists from the early 1970s. In this paper we summarise, and review available geological and isotopic data, and report results of new isotopic studies (Sm$\mathrm{Nd}, \mathrm{Pb}-\mathrm{Pb}$, and U-Pb SHRIMP analyses); field geological data obtained during the PCMEGA 2002/2003 are utilised. The structure of the region is described in terms of four tectonic terranes. Those include Archaean Ruker, Palaeoproterozoic Lambert, Mesoproterozoic Fisher, and Meso- to Neoproterozoic Beaver Terranes. Pan-African activities (granite emplacement and probably tectonics) in the Lambert Terrane are reported. We present a summary of the composition of these terranes, discuss their origin and relationships. We also outline the most striking geological features, and problems, and try to draw attention to those rocks and regional geological features which are important in understanding the composition and evolution of the PCM and might suggest targets for further investigations.
\end{abstract}

\section{Previous Work}

The Prince Charles Mountains (PCM) constitute by far the best exposed cross section through the East Antarctic Shield, extending for over $500 \mathrm{~km}$ along the drainage basin of the Lambert Glacier - Amery Ice Shelf system (Fig. 2.7-1). Australian geologists first visited this region between 1955 and 1957 . The results of geological observations were presented by Stinear (1956) and Crohn (1959), who recorded in the northern PCM (NPCM) a range of high-grade metamorphic rocks of both sedimentary and igneous origin, as well as orthopyroxene granitoids, and an overlying coal-bearing Permian-Triassic sedimentary sequence. Geological investigations in the southern PCM (SPCM) showed that the rocks there are generally of much lower metamorphic grade (green-schist to amphibolite facies) than those of the NPCM; they include thick metasedimentary sequences and are cut by abundant mafic dykes. The early workers (Tingey 1982, 1991, and references therein), on the basis of numerous Rb-Sr ages, reported the PCM as comprising two major tectonic provinces roughly corresponding to the two parts of the mountain range (NPCM and SPCM). One of the most interesting results of this study (Tingey 1982, 1991) was the recognition that presumed granitic basement and overlying metasediments in the SPCM were of Archaean

age (whole-rock Rb-Sr isochrons $2700 \pm 90,2750 \pm 400$, and $2760 \pm 200 \mathrm{Ma}$ ), whereas granulite-facies rocks of the NPCM were Meso- to Neoproterozoic (whole-rock Rb-Sr isochrons from $769 \pm 36$ to $1033 \pm 85 \mathrm{Ma}$ ). This was at variance with earlier ideas that the higher-grade rocks were likely to be older (e.g., Solov'ev 1972). Muscovite-bearing pegmatites cutting the metasediments in the SPCM were dated at 2 589, 2 100, 1995, and $1708 \mathrm{Ma}$, and it was suggested that Palaeoproterozoic, as well as Archaean sequences may be present. A few imprecise Mesoproterozoic isochron ages were also obtained (ca. $1170 \pm 230,1400 \pm 150 \mathrm{Ma}$ ); these were interpreted as reset ages, and provi- 
de some evidence for Mesoproterozoic thermal reworking of the area, possibly in response to a high-grade event in the NPCM.

Soviet geologists first visited the SPCM in 1965, and detailed geological work in the area was carried out in 19711974. Deep-seismic soundings, airborne magnetic and gravimetric surveys were carried out, and revealed the main crustal features, with the Lambert Glacier-Amery Ice Shelf rift zone being one of the most important discoveries (Kurinin and Grikurov 1982). Acritarchs were found in the metasediments, and their age was considered to be Mesoproterozoic or Meso-Neoproterozoic (Iltchenko 1972; Ravich et al. 1978). Muscovite-bearing granites were dated at ca. $500 \mathrm{Ma}$ (Halpern and Grikurov 1975). The structure of the SPCM was thought to be dominated by a NE-SW trough filled with Proterozoic sedimentary strata, the Menzies Series and Sodruzhestvo Series of Solov'ev (1972). K-Ar and $\mathrm{Rb}-\mathrm{Sr}$ dating generally confirmed the results of Tingey (1982), including Mesoto Neoproterozoic thermal reworking (1 040 and $830 \mathrm{Ma}$; Mikhalsky et al. 2001 and references therein).

Soviet geological investigations between 1982 and 1991 were concentrated in the NPCM, with a few visits to the SPCM. The results of helicopter-supported mapping and geological studies at some mountain massifs were presented by Kamenev et al. (1993). Kamenev et al. (1990,1993) proposed a threefold tectonic division of the area on structural and lithological grounds. They distinguished two structural zones (provinces or terranes): (i) the relatively conservative South Lambert province comprising Archaean granite-greenstone and granite-gneiss-schist belts (Ruker Complex), (ii) the North Lambert province underlain by a charnockite-granulite belt, which was highly mobile until Cambrian (referred to by Kamenev et al. as the Beaver Complex). These zones were thought to have been brought into contact within the area of supracrustal and granitic rocks in the central part of

the PCM (including northern Mawson Escarpment). These rocks were collectively named the Lambert Complex and were considered as either a "buffering" tectonic zone originating by interaction between granite-greenstone and charnockite-granulite belts at mid-crustal levels, or as a higher-temperature equivalents of the granite greenstone belts themselves (Kamenev et al. 1990). The Lambert Complex was thus supposed to comprise retrogressed Beaver Terrane rocks tectonically intercalated with prograde metamorphosed Ruker Terrane rocks. Kamenev and Krasnikov (1991) distinguished yet another tectonic province (Fisher Terrane) within the central PCM on the basis of its distinctive lithologies. The Fisher Terrane is characterized by essentially calc-alkaline magmatism, and likely represents an active continental margin or a collage of island arcs and foreland domains (Mikhalsky et al. 1996, 1999).

On this background, based mostly on early $\mathrm{Rb}-\mathrm{Sr}$ ages and imprecise zircon thermal ionization ages, Mikhalsky et al. (2001) described the structure of the PCM in terms of three terranes: the Ruker Terrane in the SPCM, the BeaverLambert Terrane in the central and northern PCM, and the Fisher Terrane in the central PCM, though the Fisher Terrane was considered to be a sub-terrane within the Beaver-Lambert Terrane (Fig. 2.7-1).

Recent ion microprobe studies by Boger et al. (2001, among others) showed distinctive isotopic features of rocks cropping out in the southern and central Mawson Escarpment, and basically confirmed the existence of a separate Lambert Complex as postulated by Kamenev et al. (1993), though they interpreted the origin of the Lambert Complex differently.However, Boger et al. (2001) failed to find any correlation (i.e., a Grenville-age) with the NPCM, the type area for the Beaver-Lambert Terrane of Mikhalsky et al. (2001), but showed for the first time the significance and penetrative character of the $500 \mathrm{Ma}$ Pan-African tectonics in this area.

In 2002/2003 the Prince Charles Mountains Expedition of Germany and Australia (PCMEGA) collected new geological data from an extensive area in the SPCM. In this section we present new isotopic data on rocks collected during PCMEGA and earlier expeditions to the PCM, and we address the so far enigmatic relationships between the different terranes.

\section{Isotopic Studies}

More then 60 whole-rock samples were analysed to obtain Sm-Nd model ages (Table 2.7-1). These mostly include felsic orthogneisses and schists from the Mawson Escarpment, Mt. Ruker, and scattered localities in the central and northern PCM. The Sm-Nd studies were conducted at IGGP (St. Petersburg) on a Finnigan MAT-261 solid-source mass spectrometer equipped with eight collectors operating in the mode of the simultaneous determination of the required isotopes. The measured $\mathrm{Nd}$ isotopic compositions were adjusted to ${ }^{143} \mathrm{Nd} /{ }^{144} \mathrm{Nd}=0.511860$ for the La Jolla standard. The Sm-Nd data presented in Table 2.7-1 include some obtained by the authors earlier, and mentioned by Mikhalsky et al. (2001), but the raw data

have never been published. Assuming that most of the area experienced thermal reworking at a subsequent stage of evolution, a two-stage model was applied to calculate the depleted mantle (DM) extraction ages.

The Sm-Nd model ages provide evidence for a clear distinction between the proposed terranes. Typical values are in the range 3.9-3.2 Ga for the Ruker Terrane, 3.4-3.0 Ga for the Lambert Terrane, 2.3-1.6 Ga for the Beaver Terrane, 
and 1.7-1.4 Ga for the Fisher Terrane. The age of the last significant tectonic activity that might have caused Sm-Nd fractionation ( $T$ in Table 2.7-1) is defined by zircon U-Pb data available for some localities in the PCM (Boger et al. 2000, 2001; Carson et al. 2000; Mikhalsky et al. 2001).

Three rock groups collected from Mt. Ruker yielded reasonable Sm-Nd isochrons (Fig. 2.7-2). The four green schists (presumably metavolcanics) define an isochron with an age of $2917 \pm 82 \mathrm{Ma}\left(\mathrm{MSWD}=0.33, \mathrm{Nd}_{\mathrm{i}}=0.508446\right.$; Fig.

2.7-2a). Five felsic mica schists from Mt. Ruker, however, show wide variation of isotopic ratios and do not define a reference line. This may be due to sedimentary origin of these rocks, and their isotopic inhomogeneity due to mixing of components derived from various sources. Three metagabbro-dolerite samples and mineral separates (plagioclase, biotite) define an isochron of $2878 \pm 65 \mathrm{Ma}\left(\mathrm{MSWD}=0.64, \mathrm{Nd}_{\mathrm{i}}=0.507985\right)$. Both plagioclase and biotite are thought to be metamorphic minerals, so the age of ca. $2900 \mathrm{Ma}$ is most likely to reflect that of metamorphism, although the low $\mathrm{Nd}_{\mathrm{i}}$ value precludes a long pre-metamorphic crustal residence time. The metavolcanics are likely to be roughly co-eval with the metagabbro-dolerites, but their slightly higher $\mathrm{Nd}_{\mathrm{i}}$ values suggest that they originated from a somewhat different mantle source or experienced more pronounced crustal contamination. The granophyric gabbro collected on the southern slopes of Mt. Ruker is one of only a few unaltered rocks. Its whole-rock and mineral compositions (plagioclase, clinopyroxene) define a three-point reference line corresponding to an age of $2365 \pm 65 \mathrm{Ma}$ (MSWD $\left.=1.8, \mathrm{Nd}_{\mathrm{i}}=0.508951\right)$. Two fresh dolerite dyke samples from southeastern Mt. Ruker plot roughly along this line, producing a five-point isochron of $2400 \pm 200 \mathrm{Ma}\left(\mathrm{MSWD}=4.33, \mathrm{Nd}_{\mathrm{i}}=0.508934\right)$. The initial $\mathrm{Nd}$ ratio is somewhat higher than in other analysed rock types, providing evidence that these plutonic rocks were derived from a different (less enriched) mantle source.

Hornblende-biotite, biotite granite gneisses and leucogneiss from the southern Mawson Escarpment (Ruker Terrane) have given Sm-Nd whole-rock and mineral-separate isochron age of $3231 \pm 130$ (10 samples, MSWD = 1.74; Fig. 2.7-2b). Tonalitic orthogneisses from the same area have given very imprecise Sm-Nd whole-rock (four samples), and mineral (orthopyroxene, plagioclase) whole-rock isochron ages of ca. 3000 and ca. 1900 Ma, respectively. The latter age presumably reflects a younger thermal overprint. Since orthopyroxene plots on the ca. 1900 Ma reference line, this thermal event might have caused crystallization of orthopyroxene (incipient charnockitization?). Four (out of six) metamorphic rocks of the Lambert Terrane define a poorly constrained reference line corresponding to the age of ca. $3200 \pm 200 \mathrm{Ma}$ (Fig. 2.7-2b), but occurrence of two divergent samples puts serious doubt on the significance of this reference line which may be an artifact. Inclusion of two other low- ${ }^{143} \mathrm{Nd} /{ }^{144} \mathrm{Nd}$ samples (representing Clemence Massif, and Else Platform) which were collected from the Beaver Terrane but do not follow the relevant isochron (Fig. 2.7-2c) would dramatically change the reference line to ca. $2000 \mathrm{Ga}$. Apparently the Sm-Nd data are not sufficient for the Lambert Terrane isochron age constraints.

A post-tectonic Grt-Ms-bearing pegmatite vein from Mt. Willing (Fisher Terrane; sample 39115-7) was dated by the $\mathrm{Sm}-\mathrm{Nd}$ system. A four-point isochron (whole rock, garnet, muscovite, microcline) gives an age of $925 \pm 19 \mathrm{Ma}\left(\varepsilon_{\mathrm{Nd}}=\right.$ +2.0, MSWD = 1.2; Fig. 2.7-2d).

Whole rock-mineral separate (plagioclase and two clinopyroxene fractions) Sm-Nd dating of a fresh ESE-WNW trending mafic dyke from Mt. Willing (Fisher Terrane) gave an age of $845 \pm 66 \mathrm{Ma}\left(\varepsilon_{\mathrm{Nd}}=+2.2\right.$, MSWD $=0.66$; A. Laiba, unpublished data).

We obtained $\mathrm{Pb}$ isotopic data (Table 2.7-2) on plagioclase from orthogneisses from the southern and northern Mawson Escarpment (Fig. 2.7-1), and from a thin pretectonic granitic sheet (granite-gneiss) in the northern Mawson Escarpment (Lines Ridge). Plagioclase from all the orthogneisses reveals consistently low lead isotopic ratios $\left({ }^{206} \mathrm{~Pb} /{ }^{204} \mathrm{~Pb}=13.72-14.22 ;{ }^{207} \mathrm{~Pb} /{ }^{204} \mathrm{~Pb}=13.21-13.52\right)$, while the granite plagioclase has much higher ratios (18.66 and 16.19). These data indicate that the granite originated much later than the granite-gneiss, probably in Pan-African time.

Seven samples were analysed for zircon U-Pb isotope ratios. The measurements were carried out with a SHRIMP-II ion microprobe at the Centre of Isotopic Research (VSEGEI, St. Petersburg, Russia). Five to ten zircon grains from each sample were studied. Each analysis consisted of five scans through the mass range, the spot diameter was about $18 \mu \mathrm{m}$ and the primary beam intensity about $4 \mathrm{nA}$. The $\mathrm{Pb} / \mathrm{U}$ ratios have been normalized relative to a value of 0.0668 for the ${ }^{206} \mathrm{~Pb} /{ }^{238} \mathrm{U}$ ratio of the TEMORA reference zircons, equivalent to an age of $416.75 \mathrm{Ma}$ (Black and Kamo 2003). The results are summarized in Table 2.7-3 (for details see Mikhalsky et al. in press).

Zircon grains in all samples but one have prismatic to long prismatic shape suggestive of magmatic origin, those from the Lambert Terrane are mostly somewhat rounded, and zircons from the Ruker Terrane exhibit thin oscillatory zoning. Zircon grains in sample 33536 are isometric, and most are rounded, which suggests metamorphic ori gin. Visual cores are rare. Cathodoluminescent images usually show high-U irregular areas which tend to outer grain parts. Nevertheless high-U, and low-U areas, as well as cores, inner and outer parts are indistinguishable in terms of $\mathrm{U}-\mathrm{Pb}$ isotopic ratios. Most analyses are concordant or nearly concordant. 
These dates are in good agreement with those obtained by Boger et al. (2001), who reported granite-gneiss emplacement in Ruker Terrane at $3170 \mathrm{Ma}$, with an inherited age of $3370 \mathrm{Ma}$.

In the following sections we outline the main geological features of the PCM from earlier work, as well as considering the new and recently published geochronological data, and the geological observations made by one of the authors (E. V. M.) during the 2002/2003 PCMEGA expedition.

\section{Ruker Terrane}

The Ruker Terrane comprises low- to medium-grade metasediments, minor metavolcanics, and granite to granitegneiss locally cut by abundant variously deformed and metamorphosed mafic dykes and sills of two or three generations.

The rocks from the Ruker Terrane have highly varied T(DM2) values, but most lie between 3900 and 3200 Ma, thus reflecting the most ancient protolith ages. However, some felsic schists from Mt. Ruker have lower T(DM2) ages of $<3$ $000 \mathrm{Ma}$, providing evidence for either source heterogeneity, or addition of juvenile material during the late Archaean. Much more isotopic data are needed to clarify the geological history of the Ruker Terrane.

The rocks of the Ruker Terrane appear to constitute a granite-gneiss basement and one or more supracrustal cover sequences. Presumably cover sequences include the medium-grade Menzies Series of quartzitic to pelitic composition - cut by a 2580 Ma pegmatite (Tingey 1991) - low-grade metasediments, metavolcanics and BIF of the Ruker Series, and low-grade clastic metasediments of the Sodruzhestvo Series. The latter was long believed to be of Mesoto Neoproterozoic age, based on acritarch studies (Iltchenko 1972) and the apparent lack of presumed Mesoproterozoic mafic dykes, abundant throughout most of the SPCM (Tingey 1991). The chemical composition of these dykes suggested a correlation with Mesoproterozoic mafic dykes in Enderby Land and the Vestfold Hills, which allowed these dykes to be used as a stratigraphic marker. However, during the PCMEGA field work, mafic bodies were found to intrude the Sodruzhestvo Series at Cumpston Massif. But, until the age of these mafic bodies is determined, the age of the Sodruzhestvo Series remains uncertain, and well may be either Neoarchaean or Neoproterozoic. We doubt the validity of using mafic dykes uncorroborated as a stratigraphic marker anyway, and the geological composition and structure rather point to its relatively young age.

The crystalline basement of the Ruker Terrane includes granite and granite-gneiss (Mawson Orthogneiss); it has been suggested that the Menzies Series rocks together with the Mawson Orthogneiss represent a single complex infracrustal assemblage (Kamenev et al. 1990). Two rock associations were distinguished within the Mawson Orthogneiss on compositional grounds (Mikhalsky et al. 2001):

(a) Y-depleted tonalitic to trondhjemitic orthogneiss similar to the tonalite-trondhjemite-granodiorite (TTG) associations, thought to represent new sialic crust formed by hydrous partial melting of a garnet-and/or amphibole-bearing mafic source, and (b) Y-undepleted granite-gneisses enriched in many large-ion and high-field-strength elements, suggesting affinities with A-type granites. TTGlike association seems to be restricted to the south-eastern part of the exposed Ruker Terrane (southern Mawson Escarpment, Cumpston Massif, and Blake Nunataks). The A-type granitegneisses are more widespread.

Tingey (1982) distinguished three metamorphic events in this area. Granitic basement rocks show evidence for an early (presumably Archaean) high-grade event since they are commonly migmatitic. There is possible petrographic evidence for granulite-facies conditions during early

metamorphism: mafic granulite crops out at Mt. Newton, and orthopyroxene-bearing tonalitic gneiss in the southern Mawson Escarpment. It is unclear whether the latter represents an earlier metamorphic or magmatic event, or subsequent charnockitization. These orthopyroxenebearing rocks do have some primary magmatic textures, but their field appearance clearly indicates subsequent fluid infiltration (charnockitization?).

Later metamorphic events were attributed by Tingey (1982) to various amphibolite to greenschist facies events of Mesoproterozoic to Early Palaeozoic age, but this interpretation is not generally confirmed by recent isotopic studies. The geological history of the Ruker Terrane may go back to ca. $3395 \mathrm{Ma}$ (age of a granite cobble in the Sodruzhestvo Series; Mikhalsky et al. in press), i.e., the initial geological processes were Early Archaean, which is also indicated by Sm-Nd model ages (up to 3.9-3.8 Ga). Emplacement of trondhjemite, likely derived by melting of mafic rocks, occurred at ca. $3380 \mathrm{Ma}$ and granite at ca. 3 180-3 $170 \mathrm{Ma}$ (Boger et al. 2001; Mikhalsky et al. in press). The minimum age of subsequent deformation is constrained by an age of ca. $2645 \mathrm{Ma}$ for an undeformed pegmatite (Boger et al. 2001), and might be approximated by a Sm-Nd isochron age of ca. $3170 \mathrm{Ma}$ and thermal events recorded by SHRIMP zircon ages of 3145 , and $3110 \mathrm{Ma}$.

Biotite granite emplacement at Mt. Ruker was dated at $3005 \pm 57 \mathrm{Ma}$ (conventional zircon studies, Mikhalsky et al. 2001). This granite is of near-minimum-melt composition. These granites have quite strongly fractionated REE patterns with negative Eu anomalies (Mikhalsky et al. 2001), consistent with melting of felsic crustal rocks and plagiocla- 
se fractionation. The ca. $3000 \mathrm{Ma}$ granite plutons are more fractionated than most felsic orthogneisses from the Ruker Terrane, but their geochemistry suggests they were derived by partial melting of such rocks (Mikhalsky et al.

2001).

Zircons from Ruker Series metamorphic rocks have a wide range of isotopic ratios indicating a number of thermal events between approximately 3175 and 2500 Ma with a major Pb loss at ca. $500 \mathrm{Ma}$ (Mikhalsky et al. 2001). Metamorphism at Mt. Ruker occurred at ca. 2900 Ma as evidenced by our Sm-Nd data, which gives a reasonably lower age limit for the Ruker Series, which is probably Mesoarchaean (TDM 3.3-2.9 Ga).

Minor gabbro and dolerite emplacement at Mt. Ruker is dated at $2365 \pm 65 \mathrm{Ma}$ ( $\mathrm{Sm}-\mathrm{Nd}$, this study). The age of these rocks roughly corresponds to the Palaeoproterozoic Rb-Sr ages of high-Mg dykes in the Vestfold Hills and Enderby Land (Collerson and Sheraton 1986; Sheraton and Black 1981). However, none of the analysed Mt. Ruker rocks are of high-Mg composition, although a number of undated high-Mg ultramafic dykes have been reported from this area (Mikhalsky et al. 2001).

Sm-Nd data on Opx-bearing tonalitic gneiss from the southern Mawson Escarpment show that a thermal event occurred at about $1900 \mathrm{Ma}$, although the nature of this event is unclear (we believe fluid infiltration was involved).

The earliest mafic dykes in the Mawson Escarpment are Neoarchaean (pre-2 650 Ma, Boger et al. 2001), while many others apparently post-date the ca. 1900 Ma fluid infiltration event, and thus may well be Mesoproterozoic.

An important feature of the Ruker Terrane is the presence of a tectonic melange of metamorphosed ultramafic rocks, including peridotites, in shear zones in the southern Mawson Escarpment, as well as similar, but much less deformed rocks at Mt. Ruker. These rocks have tholeiite to basaltic komatiite (Mt. Ruker) or peridotitic komatiite (Mawson Escarpment) compositions. The Mawson Escarpment rocks have non-chondritic major and trace element ratios (CaO/ $\mathrm{TiO}_{2}, \mathrm{CaO} / \mathrm{Al}_{2} \mathrm{O}_{3}, \mathrm{Zr} / \mathrm{Y}, \mathrm{Ti} / \mathrm{Zr}$, etc.), which may be attributed to cumulus processes, and therefore it is possible that they are of intrusive rather than volcanic origin (Mikhalsky et al. 2001). Whatever their origin, these rocks may mark some Archaean sutures. Their age at Mt. Ruker has already been shown to be Archaean (as they are apparently pre-metamorphic, i.e. pre2 $900 \mathrm{Ma})$.

\section{Beaver and Fisher Terranes}

The Beaver Terrane is a long-lived polymetamorphic and polydeformational mobile belt, active between 1150 and $900 \mathrm{Ma}$. Peak metamorphic conditions and maximum deformation were attained at ca. $990 \mathrm{Ma}$, the waning stages lasting until ca. 940 to $900 \mathrm{Ma}$ (Boger et al. 2000). A thick tectonic slice of serpentinite in the Radok Lake area (a protrusion?), probably co-eval with $\mathrm{D}_{4}$ deformation and thrusting dated at ca. $900 \mathrm{Ma}$ by Boger et al. (2000), gave an age of $1165 \pm 13 \mathrm{Ma}$ (conventional U-Pb monazite analysis, Mikhalsky et al. 2001), which reflects a Mesoproterozoic event of unknown nature about 150 Ma before the metamorphic peak in the Beaver Terrane.

Typical Beaver Terrane lithologies in the NPCM are high-grade paragneiss and felsic to mafic orthogneiss, granite gneiss, minor metagabbro, and late-tectonic orthopyroxene granitoids. Igneous protoliths of many granulites may have been produced in a subduction-zone environment (Munksgaard et al. 1992). The rocks of the Beaver Terrane have T(DM2) ages mostly in the range 2.3-1.6 Ga, indicating that crust-forming processes occurred in the Palaeo- to Mesoproterozoic. One much older model age (3.2 Ga) for an orthogneiss from Else Platform suggests the involvement of a more ancient source in that area. This area in fact is located within the Lambert Glacier rift system and may represent a boundary between, or comprises a collage of, various crustal blocks or sub-terranes.

The southern, though not marginal, part of the Beaver Terrane consists of a distinctive rock association of lowto medium-grade metamorphic rocks (metavolcanics), minor metasediments, granite and gabbro (the Fisher Terrane). The Fisher Terrane rocks have DM2 model ages of 1.7-1.4 Ga (Mikhalsky et al. 2001, and references therein), which are similar to model ages obtained for the Beaver Terrane, although they tend to be somewhat younger. However, the mantle source of these rocks was probably not typical depleted mantle, having lower $\varepsilon_{\mathrm{Nd}}=+2$ to +4 at $1.3 \mathrm{Ga}$ (Mikhalsky et al. 1996). The mantle source composition of the Beaver Terrane rocks cannot easily be evaluated at the present stage of this study.

The Fisher Terrane is largely composed of mafic to felsic schist and gneiss of apparent calc-alkaline affinity. Metabasalts plot within the island-arc or volcanic-arc fields in geochemical discrimination diagrams. Most metavolcanics, especially basaltic andesite and andesite show a prominent negative $\mathrm{Nb}$ anomaly on a primitive mantle-normalised spidergram. Granitoids also plot in volcanic-arc fields in discrimination diagrams (Mikhalsky et al. 2001, and references therein). These features point to formation of the Fisher Terrane rocks in a subductionrelated continental-margin environment. Volcanic activity was dated at ca. 1300 Ma by both conventional (Beliatsky et al. 1994) and SHRIMP (Kinny et al. 1997) zircon studies. Emplacement of tonalite, granite, and gabbro intrusives ceased by about $1190 \mathrm{Ma}$, lower amphibolitefacies metamorphism occurred at ca. $1100 \mathrm{Ma}$, and late granitoids were emplaced at ca. $1020 \mathrm{Ma}$ (Mikhalsky et al. 2001, and references therein). Most of these ages do not correlate with known events in the Beaver 
Terrane. However, the youngest pegmatite vein in the Fisher Terrane (925 $\pm 19 \mathrm{Ma}$, this study) is co-eval with granitic dykes in the Beaver Terrane ( $930 \pm 14$, Boger et al. 2000; $910 \pm 18$, Carson et al. 2000). Such dykes mark the waning stages of deformation in the Beaver Terrane, whereas deformation probably ceased by ca. 1000 Ma in the Fisher Terrane, although thermal or metamorphic event at ca. $810 \mathrm{Ma}$ is recorded by zircon growth in metagabbro.

The relationship between the Fisher and Beaver Terranes remain the most enigmatic feature of PCM geology. The Fisher Terrane apparently escaped the early Neoproterozoic high-grade metamorphic event which affected areas both north and south of it. However, only Rb-Sr age data are available for the latter area and modern geochronological studies are needed. Until such data are available, a correlation between this area and the rest of the NPCM must remain uncertain. It is possible that this area is allochthonous. On the other hand, a correlation with the Palaeoproterozoic Lambert Terrane (see below) is also possible.

It should be noted that a single zircon fraction from probably tuffaceous felsic schist from the Fisher Massif yielded a discordant ${ }^{207} \mathrm{~Pb} /{ }^{206} \mathrm{~Pb}$ age of ca. $2560 \mathrm{Ma}$ (Beliatsky et al. 1994), providing evidence for an Archaean component in the sediment source region.

A few occurrences of amphibolite-facies rocks in the NPCM (e.g., Radok Lake area, Boger et al. 2000; Mt. Meredith, Kinny et al. 1997) support the idea of a more widespread occurrence of Fisher Terrane or Lambert Terrane rocks. A large amount of the Beaver and Fisher Terranes probably originated in the Palaeo(?)- and Mesoproterozoic as accretional complexes formed by collision of magmatic arcs and back-arc basins prior to final collision between the large lithospheric blocks. One of these is represented by the Ruker Terrane andVestfold Hills and the other comprising Enderby Land and India. The Mesoproterozoic orogen of the NPCM (and probably of a wider areas) is thus probably of accretional, rather than collisional, type.

A notable feature of the Fisher Terrane is the presence of roughly east-west-trending mafic dykes at Mt. Willing (845 $\pm 66 \mathrm{Ma}, \mathrm{A}$. Laiba,unpublished data). These dykes are the only known Neoproterozoic mafic igneous rocks in the region, if not in the whole of East Antarctica, and may be a manifestation of Rodinia break-up. Dyke swarms of broadly similar age (ca. $830 \mathrm{Ma}$ ) are known from South China (Li 1999) and central Australia (Wingate 1998), although the Mt. Willing dykes have different chemical composition (A. Laiba, unpublished data).

\section{Lambert Terrane}

The area of the central and northern Mawson Escarpment, Clemence Massif, and some outcrops on the western flank of the Lambert Glacier (Mt. Johns, Shaw Massif, and a few smaller nunataks) was distinguished by Kamenev et al. (1993) as the Lambert Terrane. These authors also included Mt. Meredith and nearby outcrops into this terrane which has long been a debatable tectonic province. This area is underlain by high-grade orthogneiss (mostly biotitequartz-feldspar gneiss) and paragneiss, which differs from the Ruker Terrane rocks in by being generally more strongly layered, containing significant garnet, and generally lacking hornblende, allanite and titanite (Mikhalsky et al. 2001, and references therein). Prominent rock types are metapelite, metapsammite,calc-silicate, and marble. Significant amounts of weakly deformed mafic rocks crop out in the Rofe Glacier area, and ultramafic bodies (probably thrusted tectonic slabs of orthopyroxenite and amphibolite) occur in some localities, suggesting the presence of a suture zone or other major crustal discontinuity. Our U-Pb data argue for a Pan-African age of this tectonic activity, which may have involved folding and thrusting of a mafic to ultramafic underplate or possibly oceanic crust, into granitic basement.

Metamorphic grade in the Lambert Terrane is generally lower than in the Beaver Terrane, but granulite-facies assemblages are known from the very northern part of

Mawson Escarpment and Clemence Massif (Mikhalsky et al. 2001). However, the detail geological and geochronological data for Clemence Massif are yet lacking and its tectonic position is not clear. We favour its inclusion into the Beaver Terrane at the present stage of study on the basis of Grenville-age Rb-Sr dating by Tingey (1982), although available single Sm-Nd model T(DM) age of $3188 \mathrm{Ma}$ implies the presence of an ancient source region, which is not typical for the Beaver Terrane.

In spite of its somewhat different lithological composition the whole area was tentatively included in the Beaver-Lambert Terrane (Mikhalsky et al. 2001) on the basis of very similar Rb-Sr ages. However, recent geochronological work by Boger et al. (2001) and our new data demonstrate that this area more likely represents a separate terrane with its own distinct geological history.Apart from containing abundant late- to post-tectonic granites of Pan-African age (550$490 \mathrm{Ma}$, Boger et al. 2001), the zircon populations in these granites as well as in the basement orthogneisses, reveal signatures of widespread Palaeoproterozoic events (ca. 2420, 2330, 2150, 2065,1850-1600 Ma), which have not been detected in either Ruker or Beaver Terranes. It is significant that no isotopic evidence for Grenville-age events have yet been found in this area. We conclude from our new data that at least the ca. 2420 , and 2060 Ma ages re- 
flect geologically meaningful events (orthogneiss emplacement and metamorphism, respectively), but much further work is needed to fully constrain the geological history of this area.

Sm-Nd model ages (3 400-3 $000 \mathrm{Ma}$ ) of the Lambert Terrane rocks are much higher than those calculated for the Beaver Terrane (2 300-1 $600 \mathrm{Ma}$ ), but tend to be somewhat lower than those of the Ruker Terrane (>3 $200 \mathrm{Ma})$. These data provide evidence that the Lambert Terrane protoliths have a much longer crustal history than, and may not correlate with, the Beaver Terrane. Nevertheless, some of the Palaeoproterozoic ages from the Lambert Terrane correspond to reported ages of zircon growth at ca. 2 100-1 $800 \mathrm{Ma}$ in a paragneiss from Mt. Meredith (Kinny et al.

1997). That suggests that Mt. Meredith may represent a separate block of the Lambert Terrane. ${ }^{1}$

Correlation with Ruker Terrane appears difficult, as the difference between their Sm-Nd model ages is not that striking, although it is just possible that this is due to insufficient sampling of the Ruker Terrane. It is noteworthy that the spectacular mafic dyke swarm in the southern Mawson Escarpment apparently terminates at the boundary of the Ruker and Lambert Terranes, established by abrupt lithological and structural changes there (Kamenev et al. 1990; Boger et al. 2001). The dyke swarm may have its northward continuation in the Manning Glacier area, where undated north-south trending metamorphosed mafic dykes are abundant.

However, further north, in the Rofe Glacier area, the Barkell Platform, Lines Ridge, and Lawrence Hills, mafic dykes are generally lacking, except as rare thin syn-tectonic bodies.

(1) The U-Pb SHRIMP data quite recently obtained on zirkons from granitic rocks from Mt. Meredith revealed crystallization ages at C. 1300-1100 Ma and c. $500 \mathrm{Ma}$. These data demonstrate the striking age similarity with the Fisher Terrane (Mesoproterozoic), and the Lambert Terrane (Cambrian).

\section{Discussion}

The proposed four tectonic divisions (the Ruker, Lambert, Fisher, and Beaver Terranes) of the PCM seem to fit the available isotopic data. At the same time, the Fisher and Beaver Terranes are of similar origin and have similar geochemical features, and perhaps should be considered a single tectonic entity.

The SPCM, which consists of the Ruker and Lambert Terranes, are underlain by material with a long crustal history, starting mostly in the Mesoarchaean. This supports early ideas (Kamenev et al. 1993) that the Lambert Terrane represents a reworked early Precambrian assemblage (but not necessaryly the Ruker Terrane) rather than juvenile Proterozoic crust. However, it is still possible that some Proterozoic mantle-derived material is present in the Lambert Terrane. The mafic-ultramafic bodies in the Rofe Glacier area, and Lawrence Hills, although they have not yet been dated, may be examples of mantle derivates or oceanic crust.

Some rocks cropping out along the eastern flank of the Amery Ice Shelf (Reinbolt Hills, Landing Bluff) also have Archaean Sm-Nd model ages (3.15-3.0 Ga; Beliatsky, unpublished data). In contrast, the rocks of the Beaver and Fisher Terranes on the western flank of the Lambert-Amery Ice Shelf have (with few exceptions in Else Platform, and Clemence Massif) Proterozoic model ages. These data lend credence to a suggestion that the Lambert-Amery rift system may run alongside, rather than at right angles to, a major crustal (lithospheric?) discontinuity marked by abrupt chance in Sm-Nd model ages (>3.0 Ga on the eastern flank and <2.3 Ga on the western Flank of the LambertAmery Ice Shelf rift system). However, sampling on the eastern flank of the Amery lce Shelf is very sporadic, and Mesoproterozoic structures and juvenile rock associations may well run across the Lambert Glacier having not been detected yet on its eastern flank.

In the Lambert Terrane, many zircon growth events (2 400, 2 150, 2 060, 1 800, 1600 Ma, Boger et al. 2001; Mikhalsky et al. in press) support the suggestion that the Lambert Terrane experienced a long and complex Palaeoproterozoic tectonic history. Granite emplacement and high-grade metamorphism (the latter not yet dated) provide evidence for the orogenic nature of at least some of

these events. Thus we propose that the Lambert Terrane is a Palaeoproterozoic orogen, although much more work needs to be done to evaluate its origin and geological history.

Palaeoproterozoic tectonic activity is not well documented in Antarctica, except within the ca. 1.7 Ga Mawson Block (Fanning et al. 1996). This landmass is thought to comprise the Gawler Craton of South Australia, George V Land, Adélie Land, and the central Transantarctic Mountains. Its geological history includes various events dated at ca. 3 150-2 950, 2 700-2 350, 2 000, and 1 850-1 700 Ma (Fitzsimons 2003, and references therein). These ages roughly correspond to those obtained for the Lambert Terrane, thus suggesting that this part of the SPCM can be correlated with the Mawson Block. However, the Ruker Terrane rocks do not seem to correlate well with the Mawson Block, being about 200 Ma older and having older Sm-Nd model ages. Fitzsimons (2003) concluded that one or more Mesoproterozoic sutures may lie between the Mawson Block and areas west of $\sim 100^{\circ} \mathrm{E}$ (Bunger Hills), thus separating Antarctica into at least two major tectonic domains. Taking into account that the Ruker and Lambert Terranes are 
bounded to the north by the Mesoproterozoic Fisher Terrane which may partly correlate with the Fraser Complex of the Albany-Fraser Orogen, their correlation with the Mawson Block may be a reasonable suggestion. On the other hand, there is a large sub-glacial gap between the PCM and the Mawson Block, so any correlation can only be speculative. Otherwise a tentative correlation somewhat older West Australia Cratons and (or?) the Palaeoproterozoic Capricorn Orogen with zircon ages of 2 550-2 450, 2 000-1 960, 1 830-1 780, and 1 670-1 620 Ma (Cawood and Tyler 2004) might be proposed.

At the present stage of the study it is hardly possible to determine whether the Lambert Terrane assemblages originated as a distinct complex accreted onto the adjacent Ruker Terrane, and was stabilised by the Mesoproterozoic, or whether it represents a Palaeoproterozoic portion of a long-lived polycyclic mobile belt (Kamenev et al. 1990), serving as a Mesoproterozoic hinterland for the Beaver and Fisher Terranes. Perhaps the Lambert Terrane was bordered by a sinistral transcurrent zone, which was later inherited by the Lambert-Amery rift system and which separated the older crust (Lambert and Ruker Terranes) and younger crust-forming structures (e.g., Fisher Terrane) accreting southwards at a very low-angle to the present Mawson Escarpment, thus leaving it generally unaffected.

The structural position of the Fisher Terrane remains enigmatic due to inadequate knowledge of the geology of the area immediately to the south. It was suggested that the Fisher Terrane accreted onto an older crustal block (Mikhalsky et al. 2001). However, if the proposed correlation between Mt. Meredith and the Lambert Terrane is correct, then the Fisher Terrane would cut across the latter, which might imply an aulocogen origin of the Fisher Terrane. The geographic position of the Fisher Terrane right along the strike of Mesoproterozoic dyke swarms in the Vestfold Hills, if not just coincidence, could be consistent with such speculation. However, rock compositions in the Fisher Terrane are not consistent with this scenario, which would exclude any oceanic opening, and hence Pan-African suturing, since the Neoproterozoic.

Another striking feature of the SPCM is the widespread emplacement of Pan-African granite bodies, as well as prominent deformation of the similar age which caused folding and brought ultramafic material to up-per crust. Pan-African processes are widely regarded as the consequence ofcontinental collision (e.g.,Boger et al. 2001; Fitzsimons 2003), but we believe that mafic underplate might have been an important tectonic factor as well.

Muscovite-biotite pegmatite and granite veins and dykes show syn- to post-emplacement deformation, providing evidence for extensive tectonic activity during magmatism, which puts doubt on the post-tectonic or anorogenic origin for these rocks advocated by the early researchers (Tingey 1991). It is noteworthy that Pan-African granitic rocks in the SPCM differ in many geochemical respects from otherwise similar rocks in the NPCM, being higher in $\mathrm{Al}_{2} \mathrm{O}_{3}$ and $\mathrm{Na}_{2} \mathrm{O}$, and lower in light REE, $\mathrm{U}$, and Th (Mikhalsky et al. 2001). These features indicate derivation from different crustal sources.

The east-west-trending Neoproterozoic mafic dykes within the Fisher Terrane may indicate a response to roughly north-south direction of Neoproterozoic extension due to Rodinia breakup. Assuming that the subsequent Pan-African compression inherited this general orientation, we believe that any Pan-African suture zone, if it exists, shouldtrend east-west, ratherthan north-south.

\section{Acknowledgments}

EVM participated in the PCMEGA 2002/2003 as a guest scientist, and very much appreciates an invitation from the scientific leaders N. W. Roland (BGR, Hannover) and C. J. L. Wilson (University of Melbourne), the friendly logistic support by the ANARE team, and invaluable field assistance by the PCMEGA participants. S. A. Sergeev is thanked for carrying out the SHRIMP analyses at the Isotopic Centre (VSEGEI, St Petersburg). We thank J. Sheraton for his valuable comments on the manuscript, and N. W. Roland and an anonymous reviewer for their helpful and constructive review. $\mathrm{H}$. Toms is greatly thanked for improving the language. This contribution was partly made possible by a grant from the Deutsche Forschungsgemeinschaft to EVM.

\section{References}

Beliatsky BV, Laiba AA, Mikhalsky EV (1994) U-Pb zircon age of the metavolcanic rocks of Fisher Massif (Prince Charles Mountains, East Antarctica). Antarctic Sci 6:355-358

Beliatsky BV, Mikhalsky EV, Sergeev SA (in prep.) Zircon U-Pb SHRIMP data for the Prince Charles Mountains rocks Black LP, Kamo SL, et al. (2003) TEMORA 1: A new zircon standard for U-Pb geochronology. Chem Geol 200:155170

Boger SD, Carson CJ, Wilson CJL, Fanning CM (2000) Neoproterozoic deformation in the Radok Lake region of the NPCM: evidence for a single protracted orogenic event. Precambrian Res 104:1-24 
Boger SD,Wilson CJL, Fanning CM (2001) Early Paleozoic tectonism within the East Antarctic craton: the final suture between east and west Gondwana? Geology 29:463-466

Carson CJ, Boger SD Fanning CM, Wilson CJL, Thost D (2000) SHRIMP U-Pb geochronology from Mt. Kirkby, northern Prince Charles Mountains, East Antarctica. Antarctic Sci 12:429-442

Cawood PA, Tyler IM (2004) Assembling and reactivating the Proterozoic Capricorn Orogen: lithotectonic elements, orogenies, and significance. Precambrian Res 128:201-218

Collerson KD, Sheraton JW (1986) Age and geochemical characteristics of a mafic dyke swarm in the Archaean Vestfold Block, Antarctica: inferences about Proterozoic dyke emplacement in Gondwana. J Petrol 27:853-886

Crohn PW (1959) A contribution to the geology and glaciology of the western part of AAT. BMR Bull 52

Fanning CM, Daly SJ, Bennett VC, Menot RP, Peucat JJ, Oliver RL, Monnier O (1995) The "Mawson Block": once contiguous Archean to Proterozoic crust in the East Antarctic shield and Gawler craton, Australia. ISAES VII Abstracts volume, Siena

Fitzsimons ICW (2003) Proterozoic basement provinces of southern and southwestern Australia, and their correlation with Antarctica. In: Yoshida M, et al. (eds) Proterozoic East Gondwana: supercontinent assembly and breakup. Geol Soc London Spec Pub 206:93-130

Halpern M, Grikurov GE (1975) Rubidium-strontium data from the southern Prince Charles Mountains. Antarctic J US 10:9-15

Iltchenko LN (1972) Late Precambrian acritarchs of Antarctica. In: Adie RJ (ed) Antarctic geology and geophysics. Universitetsforlaget, Oslo, pp 599-602

Kamenev EN, Krasnikov NN (1991) The granite-greenstone terrains in the southern Prince Charles Mountains. $6^{\text {th }}$ Internat Sympos Antarctic Earth Sci, Tokyo. Abstract, pp 264-268

Kamenev EN, Kameneva GI, Mikhalsky EV, Andronikov AV (1990) The Prince Charles Mountains and Mawson Escarpment. In: IvanovVL, Kamenev EN (eds) The geology and mineral resources of Antarctica. Nedra, Moscow, pp 67-113, (in Russian)

Kamenev EN, Andronikov AV, Mikhalsky EV, Krasnikov NN, Stuewe K (1993) Soviet geological maps of the Prince Charles Mountains. Austral J Earth Sci 40:501-517

Kinny PD, Black LP, Sheraton JW (1997) Zircon U-Pb ages and geochemistry of igneous and metamorphic rocks in the northern Prince Charles Mountains. AGSO J Austral Geol Geophys 16:637-654

Kurinin RG, Grikurov GE (1982) Crustal structure of part of East Antarctica from geophysical data. In: Craddock C (ed) Antarctic geoscience. University of Wisconsin Press, Madison, pp 895-901

Li ZX, Li XH,Kinny PD,Wang J (1999) The breakup of Rodinia: did it start with a mantle plume beneath South China? Earth Planet Sci Letters 173:171-181

Mikhalsky EV, Sheraton JW, Laiba AA, Beliatsky BV (1996). Geochemistry and origin of Mesoproterozoic metavolcanic rocks from Fisher Massif. Antarctic Sci 8:85-104

Mikhalsky EV, Laiba AA, Beliatsky BV, Stüwe K (1999) Geological structure of Mount Willing (Prince Charles Mountains, East Antarctica), and some implications for metamorphic rock age and origin. Antarctic Sci 11:338-352

Mikhalsky EV, Sheraton JW, Laiba AA, et al. (2001) Geology of the Prince Charles Mountains, Antarctica. AGSO Bull 247

Mikhalsky EV, Beliatsky BV, Sheraton JW, Roland NW (in press) Two distinct Precambrian terranes in the southern Prince Charles Mountains, East Antarctica: SHRIMP dating and geochemical constraints. Gondwana Res

Munksgaard NC, Thost DE, Hensen BJ (1992) Geochemistry of Proterozoic granulites from northern Prince Charles Mountains, East Antarctica. Antarctic Sci 4:59-69

Ravich MG, Solov'ev DS, Fedorov LV (1978) Geological structure of Mac Robertson Land. Gidrometeoizdat, Leningrad, (in Russian)

Sheraton JW, Black LP (1981) Geochemistry and geochronology of Proterozoic tholeiite dykes of East Antarctica: evidence for mantle metasomatism. Contrib Mineral Petrol 78:305-317

Solov'ev DS (1972) Geological structure of the mountain fringe of the Lambert Glacier and the Amery Ice Shelf. In: Adie RJ (ed) Antarctic geology and geophysics. Universitetsforlaget, Oslo, pp 573-577

Stinear BH (1956) Preliminary report on operations from Mawson base, ANARE 1954-55. BMR Record 1956(44)

Tingey RJ (1982) The geologic evolution of the Prince Charles Mountains

- an Antarctic Archean cratonic block. In: Craddock C (ed) Antarctic geoscience. University of Wisconsin Press, Madison, pp 455-464

Tingey RJ (1991) The regional geology of Archaean and Proterozoic rocks in Antarctica. In: Tingey RJ (ed) The geology of Antarctica. Clarendon Press, Oxford, pp 1-58

Wingate MTD, Campbell IH, Compston W, Gibson GM (1998) Ion microprobe U-Pb ages for Neoproterozoic basaltic magmatism in south-central Australia and implications for the breakup of Rodinia. Precambrian Res 87:135-159 


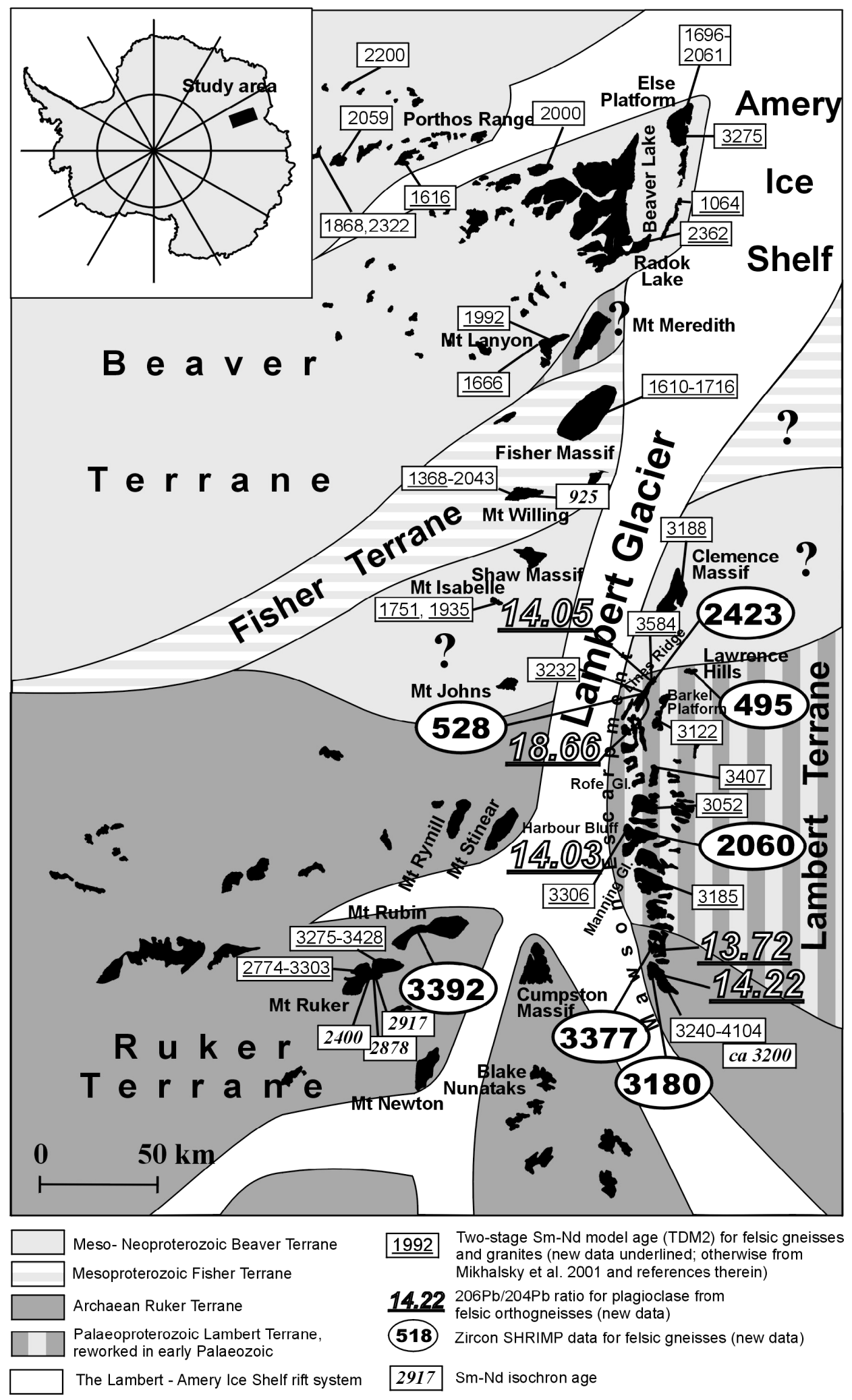

Fig. 2.7-1. Overview of Prince Charles Mountains tectonic subdivisions, and isotopic data locality map 

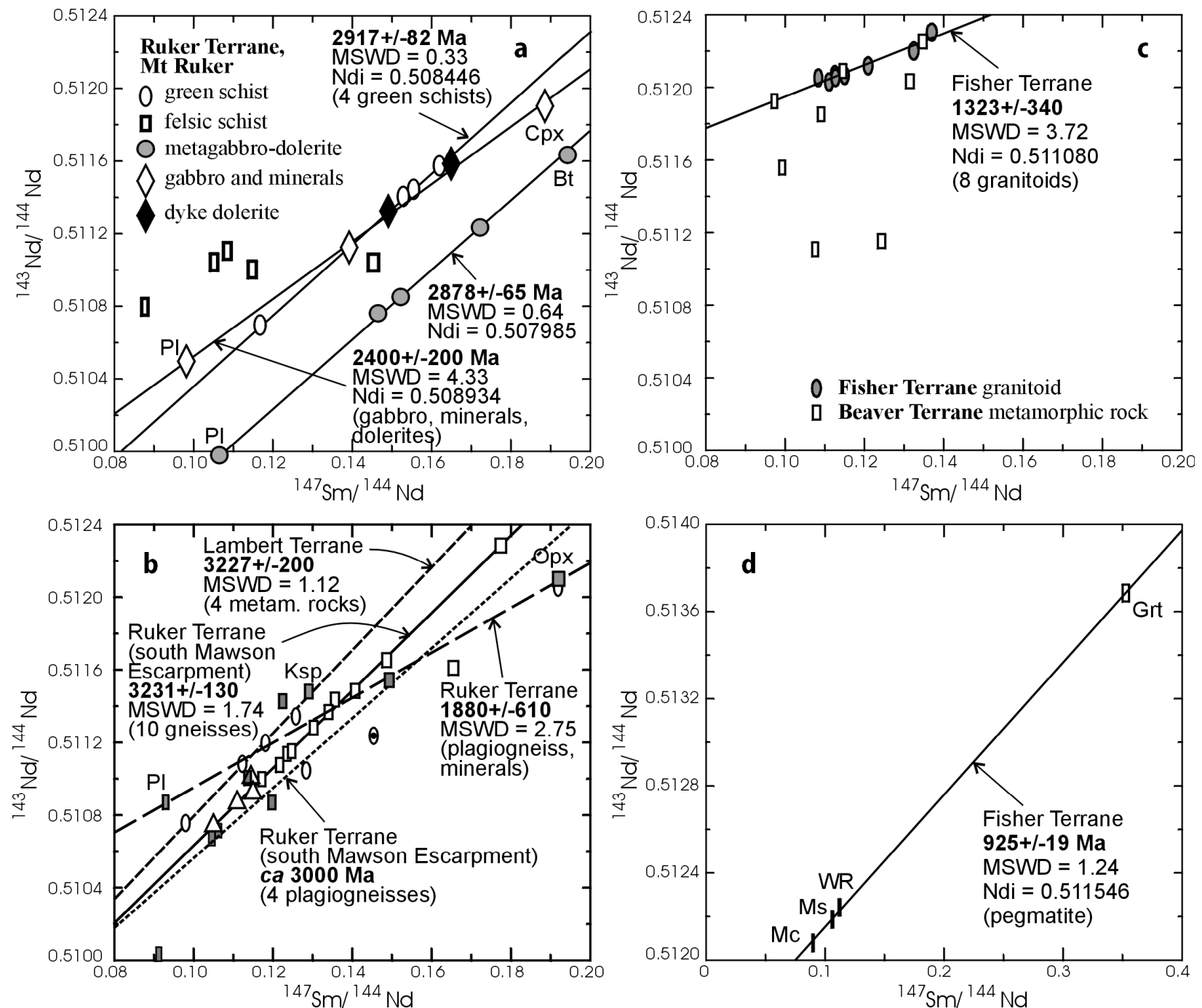

Lambert Terrane

0 metamorphic rock, granitoid $\theta$ granite-gneiss, Pan-African

\section{Ruker Terrane}

口 Bt-Hbl, Bt gneiss or leucogneiss, ME

( Bt-Hbl, Bt, Opx plagiogneiss or

bandedgneiss, and minerals, ME

$\triangle$ granitoid, Mt Ruker

Fig. 2.7-2. Sm-Nd isotope diagrams: a metamorphic and mafic plutonic rocks, Mt. Ruker; b metamorphic rocks and granitoids from Lambert Terrane and Ruker Terrane (ME: Mawson Escarpment); c granitoids from Fisher Terrane, and metamorphic rocks from Beaver Terrane; d pegmatite from Fisher Terrane (Mt. Willing). Symbols not to uncertainty scale 
Table 2.7-1. doi:10.1594/PANGAEA.611692

\begin{tabular}{|l|l|l|l|l|l|}
\hline Sample & Rock type & Locality & ${ }^{206} \mathrm{~Pb} /{ }^{204} \mathrm{~Pb}$ & ${ }^{207} \mathrm{~Pb} /{ }^{204} \mathrm{~Pb}$ & ${ }^{208} \mathrm{~Pb} /{ }^{204} \mathrm{~Pb}$ \\
\hline 33504 & Bt granite-gneiss & North ME & 14.047 & 13.413 & 34.423 \\
\hline $33507-1$ & Pre-tectonic granite-gneiss & North ME & 18.663 & 16.189 & 39.612 \\
\hline 33536 & Bt granite-gneiss & Central ME & 14.033 & 13.405 & 34.411 \\
\hline $33013-8$ & Bt-Hbl granite-gneiss & South ME & 14.224 & 13.519 & 34.589 \\
\hline $33129-6$ & Bt plagiogneiss & South ME & 13.725 & 13.210 & 34.112 \\
\hline
\end{tabular}

Table 2.7-2. Lead isotope composition of plagioclase from metamorphic rocks of Mawson Escarpment

\section{Rock}

\section{Ruker Terrane}

Granite cobble in Mt. Rubin sediments

Plagiogneiss, south. Mawson Esc.

Hbl-Bt granite, south Mawson Esc.

\section{Age (Ma)}

$3392 \pm 6$

$626 \pm 51$

$3377 \pm 9$

3145

$3180 \pm 9$

3110

$587 \pm 170$
Crystallization Thermal event

Crystallization Thermal event

Crystallization Metamorphism Thermal event

\section{Lambert Terrane}

Orthogneiss, northern Mawson Esc.

Orthogneiss, central Mawson Esc.

Pre-tectonic granite-gneiss, northern Mawson Esc.

Syn-tectonic pegmatite, Lawrence Hills

$\begin{array}{ll}2423 \pm 18 & \text { Crystallization } \\ 2060 \pm 202 & \text { Metamorphism } \\ 330 & \text { Inheritance } \\ 528 \pm 6 & \text { Crystallization } \\ 495 \pm 18 & \text { Crystallization } \\ 142 \pm 28 & \text { Thermal event(?) }\end{array}$

Table 2.7-3. Zircon ion-microprobe ages; for further details see Mikhalsky et al. (in press) 